\title{
Manajemen Kurikulum Terpadu di Pondok Pesantren Modern Daarul Huda Banjar
}

\author{
Abdul Hakim \\ Institut Agama Islam Darussalam (IAID) Ciamis \\ Email: abdul_hakim16@yahoo.co.id \\ N. Hani Herlina \\ Program Pascasarjana, Institut Agama Islam Darussalam (IAID) Ciamis \\ Email: haniherlina.iaid@gmail.com
}

Received: November 24, 2017 | Accepted: Fabruary 11, 2018

\begin{abstract}
This article aims to discuss integrated curriculum management of Pondok Pesantren covering: planning, curriculum structure, and implementation of integrated curriculum. Having been used qualitative research, the results of the research show that: (1) Integrated curriculum planning includes the program of faith development, noble character, science, nationality and nationality, art, entrepreneurship and technical skills, dakwah and community, leadership and management, teacher training, gender equality education, and health, tahfidz al-Qur'an; (2) curriculum structure consists of intra-curricular curriculum, co-curricular and extracurricular; (3) the implementation of integrated curriculum management in this institution is combining several curriculum types such as the formal government curriculum and curriculum of pondok pesantren.
\end{abstract}

\begin{abstract}
Abstrak
Artikel ini bertujuan untuk membahas manajemen kurikulum terpadu Pondok pesantren modern Darul Huda Banjar meliputi: perencanaan, struktur kurikulum, dan pelaksanaan kurikulum terpadu. Dengan menggunakan metode kualitatif bersifat deskriptif, sebagai hasil penelitian menunjukkan bahwa: (1) perencanaan kurikulum terpadu mencakup program pengembangan keimanan, akhlak mulia, keilmuan, kewarganegaraan dan kebangsaan, kesenian, kewirausahaan dan ketrampilan teknis, dakwah dan kemasyarakatan, kepemimpinan dan manajemen, keguruan, kepesantrenan, pendidikan kesetaraan gender, pendidikan jasmani dan kesehatan, kepramukaan, tahfidz al-Qur'an; (2) struktur kurikulum yang bersistem Kulliyatul Mu'allimin Al-Islamiyah (KMI) terdiri dari kurikulum intra-kurikuler, ko-kurikuler dan ekstrakurikuler; (3) pelaksanaan manajemen kurikulum terpadu di pondok pesantren ini adalah memadukan beberapa jenis kurikulum antara lain kurikulum formal pemerintah dan kurikulum pondok pesantren.
\end{abstract}




\section{Keywords}

Islamic education, integrated curriculum, partial curriculum

\section{Pendahuluan}

Kehadiran Pondok Pesantren membawa pesan-pesan dakwah Islamiyah dengan tujuan untuk mencetak kader ulama yang ahli agama (mutafaqqih fiddîn), memiliki kecerdasan pengetahuan (mutakallimin) dan yang mampu berdiri sendiri (mutaqawwimin). Signifikansi Pondok Pesantren sebagai basis pendidikan Islam tidak bisa diabaikan dalam kehidupan masyarakat dan bangsa Indonesia. Sebab, Pondok Pesantren merupakan subkultur yang hadir ditengah-tengah kehidupan masyarakat (Qomariyah \& Soeprajitno, 2016, p. 5).

Lembaga Pendidikan Pondok Pesantren Modern Daarul Huda dianggap telah sukses mengintegrasikan diri dengan sistem sekolah dengan memadukan kurikulum KMI (Kulliyatul Mu'allimin Al Islamiyah) Gontor, Kemendiknas, dan Kemenag, sehingga menjadi sistem pendidikan terpadu. Keterpaduan sistem pendidikan yang merupakan pengembangan dari kurikulum ini dilakukan secara sinergi dan saling mendukung antara satu dengan yang lainnya, sehingga menghasilkan sistem pendidikan pesantren yang bermutu, banyak diminati, prospektif dengan penuh prestasi dan menjadi harapan dan kebanggaan semua pihak yang terkait di dalamnya.

Pemikiran tentang perlunya manajemen kurikulum terpadu di pondok pesantren dipandang sebagai suatu kebutuhan agar dapat tetap bertahan di tengah-tengah persaingan dan globalisasi, serta sebagai landasan untuk perkembangan di masa yang akan datang. Manajemen kurikulum terpadu memiliki peran penting agar pondok pesantren dapat berjalan secara efektif dan efisien sesuai dengan tujuan yang telah ditetapkan.

Lembaga Pendidikan Pondok Pesantren Modern Daarul Huda didirikan oleh H. Tatang Abdurrohman, pada Tahun 1996. Pesantren ini dikelola dan diawasi oleh Yayasan Ibadurrahman Banjar. Lembaga Pendidikan Pesantren tersebut merupakan lembaga pendidikan yang tidak berafiliasi terhadap partai politik dan suatu organisasi sosial masyarakat manapun serta berpegang teguh pada konsep "Islam Rahmatan lil Alamin" dan falsafah "di atas dan untuk semua golongan.” Paradigma tersebut ditetapkan sebagai suatu ijtihad untuk memudahkan proses pendidikan dan pengajaran agar lebih ramah komunikatif, efektif, dan efisien dalam mendidik, mengasuh, membimbing, dan mengevaluasi para santri/ah oleh para pembina selama 24 jam berasrama. 
Dengan demikian aktivitas pendidikan dan pengajaran kurikuler, co-kurikuler, dan ektrakurikuler dapat berjalan secara konsisten.

Selanjutnya terkait konsep manajamen, manajemen berasal dari bahasa Latin, yaitu dari asal kata manus yang berarti tangan dan agare yang berarti melakukan. Kata-kata itu digabung menjadi kata kerja manager yang artinya menangani. Manager diterjemahkan ke dalam Bahasa Inggris dalam bentuk kata kerja to manage, dengan kata benda management dan manager untuk orang yang melakukan kegiatan manajemen, dan diterjemahkan ke dalam Bahasa Indonesia menjadi manajemen atau pengelolaan (Usman, 2006, p. 3). Dalam Kamus Bahasa Indonesia, manajemen adalah proses pemakaian sumber daya secara efektif untuk mencapai sasaran yang telah ditentukan; penggunaan sumber daya secara efektif untuk mencapai sasaran” (Bahasa, 2008, p. 909).

Pengertian manajemen juga terdapat dalam al-qurân, sebagaimana firman Allah SWT dalam surat as-Sajdah (32) ayat 5:

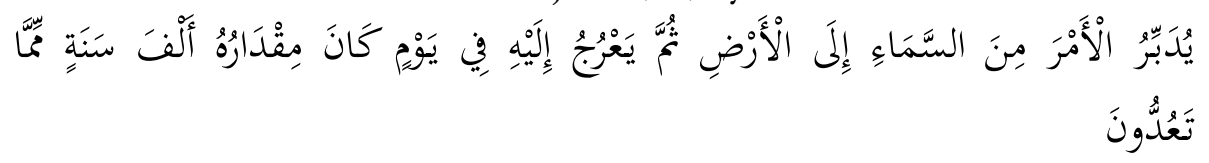

Dia mengatur urusan dari langit ke bumi, kemudian (urusan) itu naik kepadanya dalam satu hari yang kadarnya adalah seribu tahun menurut perhitunganmu. (QS. As-Sajdah, 32: 5).

Menurut Parag Diwan, Pertama, manajemen sebagai bidang studi/subjek mengacu pada prinsip-prinsip dan praktik manajemen, serta prinsip-prinsip pengetahuan dan aplikasinya secara keseluruhan. Namun pendekatan ini belum bisa memberikan sumbangan pengertian yang benar dari manajemen. Kedua, manajemen sebagai sebuah tim atau kumpulan orang mengacu sekelompok tenaga manajerial suatu perusahaan yang mempunyai fungsi pengawasan untuk dapat mengidentifikasi tujuan organisasi, dengan tolak ukur yang disepakati supaya dalam melakukan kegiatan manajerial memiliki tujuan yang sama walaupun dalam organisasi yang berbeda. Ketiga, manajemen sebagai proses mengacu pada proses yang berbeda atau langkah-langkah manajemen yang tepat mulai dari perencanaan, pengorganisasian, penyusunan pegawai, pengawasan dan pengendalian kerja. Manajemen dalam konteks ini telah didefinisikan sebagai proses mendapatkan hal yang dilakukan oleh dan bekerja sama dengan yang lain (Diwan, 1998, p. 2).

Sementara Griffin dalam bukunya Fundamentals of Management mengatakan bahwa: "Management is u ser of activities including planning and decision making, organizing, leading, and controlling directed ai using an organization's resources human. Financial, physical, and information to achieve organizational goals in an efficient and effective manner. Efficient is using resources wisely and in a cost effective way, effective is making and implementing good 
decisions". (Manajemen adalah serangkaian kegiatan termasuk perencanaan dan pengambilan keputusan, pengorgansasian, memimpin, dan mengendalikan diarahkan menggunakan sumber daya organisasi manusia, keuangan, fisik, dan informasi untuk mencapai tujuan organisasi secara efisien dan efektif. Efisien menggunakan sumber daya secara bijaksana dan dengan cara yang hemat biaya, efektif adalah membuat dan melaksanakan keputusan yang baik) (Griffin, 2008, p. 5). Sementara William H. Newman dalam (Handayaningrat, 1995, p. 20) mengemukakan bahwa fungsi manajemen adalah sebagai berikut: "perencanaan (planning), pengorganisasian (organizing), pelaksanaan (actuating), dan pengawasan (controlling)".

Berikut penejelasan mengenai fungsi - fungsi manajemen tersebut; perencanaan (planning) merupakan unsur penting dan strategis sebagai pemandu arah pelaksanaan kegiatan untuk mencapai tujuan atau sasaran yang akan dicapai. Menurut Al Hamdani "perencanaan dimaknai sebagai proses mempersiapkan kegiatan-kegiatan secara sistematis yang akan dilakukan untuk mencapai tujuan tertentu" (Al Hamdani, 2013, p. 1). Dalam bidang pendidikan perencanaan merupakan salahsatu faktor kunci efektivitas terlaksananya aktivitas pendidikan yang diharapkan bagi setiap jenjang dan jenis pendidikan pada tingkat nasional maupun lokal.

Menurut Cunningham sebagaimana dikutip oleh Pidarta bahwa perencanaan adalah menyeleksi dan menghubungkan pengetahuan, fakta-fakta, imajinasi-imajinasi, dan asumsi-asumsi untuk masa yang akan datang untuk tujuan memvisualisasi dan memformulasi hasil yang diinginkan, urutan kegiatan yang diperlukan dan perilaku dalam batas-batas yang dapat diterima yang akan digunakan dalam penyelesaian. (Pidarta, 2007, p. 1). Adapun Harjanto berpandangan bahwa perencanaan berkaitan dengan penentuan apa yang dilakukan. Perencanaan mendahului pelaksanaan, mengingat perencanaan harus mengidentifikasi persyaratan yang diperlukan dengan cara yang paling efektif dan efisien (Harjanto, 2003, p. 2).

Al Hamdani berpandangan bahwa perencanaan merupakan salah satu fungsi penting dalam kegiatan, akan mengalami kesulitan bahkan kegagalan dalam mencapai tujuan yang telah ditetapkan. Adapun langkah-langkah perencanaan adalah: (a) Menentukan/merumuskan tujuan yang hendak dicapai; (b) Mengidentifikasi masalah atau pekerjaan yang akan dilakukan; (c) Menghimpun data dan informasi yang diperlukan; (d) Menentukan tahaptahap kegiatan; (e) Merumuskan bagaimana masalah itu akan dipecahkan dan bagaimana tahapan pekerjaan akan dilakukan (Al Hamdani, 2014, p. 13).

Menurut Robbins dan Coulter dalam (Tisnawati, 2005, p. 96) perencanaan sebagai sebuah proses yang yang dimulai dari penetapan tujuan organisasi, menentukan strategi untuk pencapaian tujuan organisasi tersebut 
secara menyeluruh, serta merumuskan sistem perencanaan yang menyeluruh untuk mengitegrasikan dan mengkoordinasikan seluruh pekerjaan organisasi hingga tercapainya tujuan organisasi. Empat hal yang harus diperhatikan dalam perencanaan, yakni; tujuan yang akan dicapai dalam perencanaan, keadaan yang terjadi sekarang, alternatif pilihan kebijakan dan prioritas dalam mencapai tujuan, dan strategi penentuan cara yang terbaik untuk mencapai tujuan.

Selanjutnya mengenai pengorganisasian (organizing). Pengorganisasian sebagai fungsi manajemen memiliki pengertian yang berbeda-beda. Perbedaan tersebut disebabkan oleh perbedaan latar belakang keahlian para pakar yang memberikan pengertian itu. Dalam pandangan Sagala, pengorganisasian diartikan sebagai kegiatan membagi tugas-tugas pada orang yang terlibat dalam kerja sama pendidikan. Karena tugas-tugas ini demikian banyak dan tidak dapat diselesaikan oleh satu orang saja, maka tugas-tugas ini dibagi untuk dikerjakan oleh masing-masing organisasi. Kegiatan pengorganisasian adalah untuk menentukan siapa yang akan melaksanakan tugas sesuai prinsip pengorganisasian (Sagala, 2009, p. 49).

Adapun menurut Gibson dalam (Sagala, 2009, p. 49) pengorganisasian meliputi semua kegiatan manajerial yang dilakukan untuk mewujudkan kegiatan yang direncanakan menjadi suatu struktur tugas, wewenang, dan siapa yang akan melaksanakan tugas tertentu untuk mencapai tugas yang diinginkan organisasi.

Menurut Engkoswara dan Komariah pengorganisasian merupakan proses menyusun organisasi formal dengan melakukan aktivitas merancang struktur, menganalisis pekerjaan, menganalisis kualifikasi pekerjaan, mengelompokkan dan membagikan pekerjaan, mengkoordinasikan pekerjaan serta memantau pelaksanaan pekerjaan. Tiga langkah sebagai prosedur pengorganisasian yaitu: a) Pemerincian pekerjaan yaitu menentukan tugas-tugas apa yang harus dilakukan untuk mencapai tujuan organisasi. b) Pembagian beban pekerjaan kepada orang-orang yang memiliki kualifikasi yang tepat dan dengan beban yang rasional, tidak overloaded dan tidak terlalu ringan agar mencapai pelaksanaan yang efektif dan efisien. c) Pengadaan dan pengembangan mekanisme untuk mengkoordinasikan pekerjaan (Engkoswara \& Komariah, 2010, p. 150).

Adapun mengenai unsur pelaksanaan (actuating) dari proses manajemen, unsur pelaksanaan (actuating) merupakan fungsi manajemen yang paling utama, dalam perencanaan dan pengorganisasian lebih banyak berhubungan dengan aspek-aspek abstrak proses manajemen. Adapun fungsi actuating justru lebih menekankan pada kegiatan yang berhubungan langsung dengan orangorang dalam organisasi. 
Menurut Sagala "actuating merupakan usaha untuk menggerakan anggota kelompok sedemikian rupa sehingga mereka berkeinginan da berusaha untuk mencapai sasaran organisasi. Actuating berarti usaha mendapatkan hasil dengan penggerakan orang lain" (Sagala, 2009, p. 54). Dalam pandangan Terry dikutip Sagala "actuating berarti merangsang anggota-anggota kelompok melaksanakan tugas-tugas dengan antusias dan kemampuan yang baik". Selanjutnya Sagala juga memaparkan Pengorganisasian adalah tingkat kemampuan pimpinan sebagai pengambil pengambil kebijakan pada birokrasi pemerintah dan kepala sekolah sebagai pimpinan kegiatan pembelajaran (Sagala, 2009, p. 52).

Dalam fungsi pelaksanaan manajemen perlu adanya sebuah koordinasi. Dalam pandangan Al Hamdani, "adanya bermacam tugas/pekerjaan yang dilakukan oleh banyak orang, memerlukan adanya koordinasi dari pemimpin. Dengan koordinasi yang baik dapat dihindari kemungkinan terjadinya persaingan yang tidak sehat atau kesimpangsiuran dalam tindakan. Koordinasi dipimpin oleh koordinator yang berfungsi sebagai stabilisator antara berbagai tugas, tanggungjawab, dan wewenang untuk menjamin tercapainya relevansi, efisiensi, dan efektivitas kerja (Al Hamdani, 2014, p. 14).

Pelaksanaan (actuating) merupakan upaya menjadikan perencanaan dan pengorganisasian menjadi kenyataan, dengan melalui berbagai pengarahan dan pemotivasian agar setiap karyawan dapat melaksanakan kegiatan secara optimal sesuai dengan peran, tugas dan tanggung jawabnya. Unsur manajemen terakhir adalah pengawasan (controlling). Pengawasan merupakan bagian dari fungsi manajemen. Perencanaan, pengorganisasian dan pelaksanaan tidak akan berjalan lancar secara efektif tanpa adanya pengawasan. Dalam hal ini Handayaningrat menjelaskan "pengawasan adalah suatu proses di mana pimpinan ingin mengetahui apakah hasil pelaksanaan pekerjaan yang dilakukan oleh bawahannya sesuai dengan rencana, perintah, tujuan atau kebijaksanaan yang telah ditentukan" (Handayaningrat, 1995, p. 143).

Adapun menurut Murdick yang dikutip oleh Nanang Fattah mengatakan pengawasan merupakan proses dasar yang secara esensial tetap diperlukan bagaimanapun rumit dan luasnya suatu organisasi. Prosedurnya terdiri dari tiga tahap yaitu; (a) menetapkan standar pelaksanaan, (b) pengukuran pelaksanaan pekerjaan dibandingkan dengan standar, (c) menentukan kesenjangan (deviasi) antara pelaksanaan standar dan rencana (Fattah, 2004, p. 101).

Dalam pendapat lain pengawasan juga disebut dengan istilah supervisi, Al Hamdani berpandangan bahwa supervisi/pengawasan merupakan fungsi organik dari administrasi dan manajemen. Pengawasan bertanggungjawab tentang efektivitas dari suatu program, oleh karena itu para pengawas harus 
meneliti ada atau tidaknya kondisi-kondisi yang akan memungkinkan tercapainya tujuan pendidikan. Dengan demikian dalam fungsi supervisi yang terpenting adalah: (1) menentukan kondisi kondisi apa yang diperlukan; (2) memenuhi/mengusahakan syarat-syarat yang diperlukan itu (Al Hamdani, 2014, p. 15).

Menurut Al Hamdani, untuk mengetahui berhasil tidaknya suatu program diperlukan adanya penilaian atau evaluasi. Tiap penilaian berpegang pada rencana dan tujuan yang hendak dicapai, dengan kata lain setiap tujuan merupakan kriteria penilaian. Penilaian dalam dunia pendidikan meliputi penilaian terhadap guru, siswa, sarana dan prasaran, serta berbagai hal yang berkaitan dengan kurikulum, proses belajar mengajar, dan sebagainya (Al Hamdani, 2014, p. 16).

Dalam pandangan Engkoswara "proses dasar pengawasan meliputi tiga tahap yaitu: (1) menetapkan standar pelaksanaan; (2) pengukuran pelaksanaan; (3) menentukan kesenjangan (deviasi) antara pelaksanaan dengan standar da rencana" (Engkoswara \& Komariah, 2010, p. 220). Kurikulum terpadu atau integrated curriculum secara istilah mengandung arti perpaduan, kordinasi, harmoni, kebulatan keseluruhan. Integrated curriculum meniadakan batas-batas antara berbagai mata pelajaran dan menyajikan dalam bentuk unik atau keseluruhan. Dengan kebulatan bahan pelajaran diharapkan anak-anak mempunyai pribadi integrated yakni manusia yang sesuai atau selaras dengan sekitarnya (Nasution, 2006, pp. 195-196).

Intregated curriculum dilaksanakan melalui pengajaran unit. Menurut pendapat Caswell dalam (Nasution, 2006, p. 196) menjelaskan bahwa suatu unit mempunyai tujuan yang bermakna bagi anak yang biasanya dituangkan dalam bentuk masalah. Untuk mencegahkan masalah tersebut anak-anak melakukan serangkaian kegiatan yang saling berkaitan menghadapkan anak kepada masalah berarti merangsangnya untuk berfikir dan ia merasa tidak puas sebelum memecahkan masalah tersebut.

Kurikulum terpadu adalah kurikulum perpaduan antara beberapa jenis kurikulum di antaranya kurikulum Kemendikbud, kurikulum Kemenag, kurikulum yayasan atau Pesantren, dan Kurikulum KMI (Kulliyatul Mu'allimin Al Islamiyah) Gontor (Samdani, 2014, p. 21). Dalam pandangan Rusman "integrated curriculum meniadakan batas-batas antara berbagai mata pelajaran dan menyajikan bahan pelajaran dalam bentuk unit atau keseluruhan” (Rusman, 2009, pp. 58-59) .

Salah satu bentuk kurikulum terpadu adalah core curriculum, core yang berarti inti merupakan bahan penting yang harus diketahui oleh setiap murid pada semua tingkatan lembaga pendidikan. Menurut Abdullah Idi core curriculum dapat dikembangkan melaui 6 jenis program, yaitu: (1) Core yang 
terdiri dari sejumlah mata pelajaran yang diorganisasikan, diajarkan secara bebas untuk menunjukkan hubungan masing-masing pelajaran tersebut. (2) Core yang terdiri dari sejumlah mata pelajaran yang dihubungkan antara yang satu dengan yang lain. (3) Core yang terdiri masalah yang luas, unit kerja atau tema yang disatukan, yang dipilih untuk menghasilkan arti mengajar secara tepat dan efektif mengenai isi pelajaran tertentu. (4) Core yang menampakkan mata pelajaran yang dilebur dan disatukan. (5) Core yang merupakan masalah luas yang dapat memenuhi kebutuhan fisik dan sosial, serta masalah minat anak (peserta didik). (6) Core merupakan unit kerja yang direncanakan oleh siswa dan guru untuk memenuhi kebutuhan kelompok (Idi, 2011, pp. 173174).

Dalam menyusun kurikulum, terutama terkait bentuk penyajian bahan pelajaran (isi) atau organisasi kurikulum (isi) menurut Abdullah Idi ada dua jenis organisasi kurikulum yang bisa menjadi pilihan, yaitu kurikulum berdasarkan mata pelajaran dan kurikulum terpadu (Idi, 2011, p. 163).

Pertama, kurikulum berdasarkan mata pelajaran (subject curriculum). Berdasarkan mata pelajaran, organisasi kurikulum dibedakan menjadi tiga, yaitu separated subject curriculum, correlated curriculum, dan broad field curriculum. A) Separated subject curriculum. Separated subject curriculum adalah kurikulum dalam bentuk mata pelajaran yang terpisah-pisah, yang kurang mempunyai keterkaitan dengan mata pelajaran lain. B) Correlated curriculum. Dalam correlated curriculum, sejumlah mata pelajaran dihubungkan antara satu dengan yang lain, sehingga ruang lingkup bahan yang tercakup semakin luas. Pada saat anak didik mempelajari shalat, dapat dihubungkan dengan pelajaran Al-Qur" an seperti bacaan surat dan hadis yang dihubungkan dengan shalat. C) Broad field curriculum. Menurut Taba yang dikutip Abdullah Idi, the broad curriculum is essentially an effort to automatization of curriculum by combining several specific areas large fields (the broad curriculum) adalah usaha meningkatkan kurikulum dengan mengkombinasikan beberapa mata pelajaran). Kurikulum broad field ini merupakan kebalikan dari separated curriculum. Sebagai contohnya, mata pelajaran sejarah, geografi, ilmu ekonomi, dan ilmu politik disatukan menjadi Ilmu Pengetahuan Sosial (IPS). Mata pelajaran agama di SD juga termasuk contoh broad field, karena merupakan kumpulan dri berbagai mata pelajaran seperti fikih, tauhid, aqidah, akhlak, tarikh, hadits dan mambaca al-Qurean. Selanjutnya, Abdullah Idi berpandangan bahwa Kurikulum terpadu merupakan suatu produk dari usaha pengintegrasian bahan pelajaran dari berbagai macam pelajaran. Integrasi diciptakan dengan memusatkan pelajaran pada masalah tertentu yang memerlukan solusinya dengan materi atau bahan dari berbagai disiplin ilmu (Idi, 2011, pp. 164-166). 
Menurut Soetopo dan Soemanto sebagaimana dikutip oleh Abdullah Idi kurikulum terpadu dikelompokkan menjadi lima macam, yaitu; 1) The child centered curriculum (kurikulum yang berpusat pada anak). Maksudnya, dalam perencanaan kurikulum, faktor anak menjadi perhatian utama; 2) The social function curriculum (kurikulum fungsi sosial). Maksudnya, kurikulum ini mencoba mengeliminasi mata pelajaran sekolah dari keterpisahannya dengan fungsi-fungsi utama kehidupan sosial yang menjadi dasar pengorganisasian pengalaman belajar anak; 3) The experience curriculum (kurikulum pengalaman). Maksudnya, dalam perencanaan kurikulum, kebutuhan anak merupakan perhatian utama; 4) Development activity curriculum (kurikulum pengembangan kegiatan). Kurikulum ini sangat tergantung pada tingkat perkembangan anak yang harus dilalui; 5) Core curriculum. Menurut Sailor dan Alexander, sebagaimana dikutip oleh Abdullah Idi, core curriculum merujuk pada suatu rencana yang mengorganisasikan dan mengatur (scheduling) bagian terpenting dari program pendidikan umum di sekolah. Pada awalnya, core dimaksudkan sebagai bahan penting yang harus diketahui oleh setiap peserta didik pada semua tingkatan sekolah (Idi, 2011, pp. 170-172).

Menurut Oemar Hamalik ciri - ciri kurikulum terintegrasi adalah sebagai berikut; a) berdasarkan filsafat pendidikan demokrasi; b) berdasarkan psikologi belajar Gestalt atau organismic; c) berdasarkan landasan sosiologis dan sosial kultural; d) berdasarkan kebutuhan, minat dan tingkat perkembangan atau pertumbuhan siswa; e) bentuk kurikulum ini tidak hanya ditunjang oleh semua mata pelajaran atau bidang studi yang ada, tetapi lebih luas. Bahkan mata pelajaran atau bidang studi baru dapat saja muncul dan dimanfaatkan guna pemecahan masalah; f) sistem penyampaian menggunakan sistem pengajaran unit, baik unit pengalaman (experience unit) atau unit pelajaran (subject matter unit); g) peran guru sama aktifnya dengan peran murid. Bahkan peran murid lebih menonjol dalam Kegiatan Belajar Mengeja (KBM) dan guru bertindak sebagai pembimbing (Hamalik, 2011, pp. 158159).

Ciri kurikulum terpadu tersebut sejalan dengan pendapat James A. Beane yang mengatakan bahwa ada empat dimensi kurikulum terpadu; 1) integration of experiences (integrasi pengalaman). Beane menjelaskan pembelajaran integratif melibatkan pengalaman yang secara harfiah menjadi bagian dari pengalaman belajar yang tak terlupakan; 2) social integration (integrasi sosial). Menurut Beane di antara tujuan penting sekolah dalam masyarakat demokratis adalah memberikan pengalaman pendidikan bersama atau umum bagi kaum muda dengan karakteristik dan latar belakang yang beragam.; 3) The integration of knowledge (integrasi pengetahuan). Menurut Beane integrasi pengetahuan bila digunakan dalam kaitannya dengan kurikulum juga mengacu 
pada teori organisasi dan penggunaan pengetahuan; 4) integration as a curriculum design (integrasi sebagai desain kurikulum). Bean menjelaskan integrasi sebagai desain kurikulum adalah mengacu pada jenis desain kurikulum tertentu. Seperti yang kita lihat sebelumnya, desain yang diberi nama "integrasi kurikulum" memiliki beberapa fitur yang, bila digabungkan, membedakannya dari pendekatan lain. Pertama, kurikulum disusun seputar masalah dan isu yang memiliki kepentingan pribadi dan sosial di dunia nyata. Kedua, pengalaman belajar dalam kaitannya dengan pusat pengorganisasian direncanakan untuk mengintegrasikan pengetahuan terkait dalam konteks pusat pengorganisasian. Ketiga, pengetahuan dikembangkan dan digunakan untuk menangani pusat pengorganisasian yang saat ini sedang dipelajari daripada mempersiapkan beberapa tes atau tingkat kelas nanti (Beane, 1997, pp. 4-9).

\section{Metode Penelitian}

Penelitian ini menggunakan metode kualitatif, jenis penelitian kualitatif lapangan. dilaksanakan di Pondok Pesantren Modern Daarul Huda Kota Banjar, unit analisis dalam penelitian ini ialah manajemen kurikulum terpadu. Sumber data pada penelitian ini adalah sumber primer dan sumber skunder yang ditemukan di lokasi penelitian. Teknik pengumpulan data dilakukan dengan wawancara, observasi, dokumentasi. Uji keabsahan data peneliti menggunakan kredibilitas, dependabilitas dan konfirmabilitas. analisis data meliputi reduksi data, sajian data, penggambaran kesimpulan dan pengumpulan data sebagai suatu proses siklus.

\section{Hasil Penelitian dan Pembahasan}

Lembaga Pendidikan Pondok Pesantren Modern Daarul Huda didirikan oleh H. Tatang Abdurrohman, pada Tahun 1996. Kemudian secara terpisah Pondok Pesantren Modern Daarul Huda Putri didirikan pada tahun 2005. Pondok Pesantren dikelola dan diawasi oleh Yayasan Ibadurrahman Banjar. Lembaga Pendidikan Pesantren tersebut merupakan lembaga pendidikan yang tidak berafiliasi terhadap partai politik, dan suatu organisasi sosial masyarakat manapun. Berpegang teguh pada konsep "Islam Rahmatan lil 'Alamin" dan Falsafah "di atas dan untuk semua golongan." Paradigma tersebut ditetapkan sebagai suatu ijtihad untuk memudahkan proses pendidikan dan pengajaran agar lebih ramah komunikatif, efektif, dan efisien dalam mendidik, mengasuh, membimbing, dan mengevaluasi para santri oleh para pembina selama 24 jam 
berasrama. Dengan demikian aktivitas pendidikan dan pengajaran kurikuler, kokurikuler, dan ektrakurikuler dapat berjalan secara konstituen.

Lembaga Pendidikan Pondok Pesantren Modern Daarul Huda memiliki visi

terwujudnya lembaga pendidikan dan pusat kajian islam yang bermutu, unggul dan berakhlak karimah, serta untuk mewujudkan visi tersebut di atas ditetapkan misi yaitu meningkatkan kualitas sumber daya manusia secara terprogram dan berkesinambungan. Pesantren ini mengembangkan kurikulum yang berwawasan Al-Qur`an, Hadis, dan berbasis lingkungan. Mengembangkan sarana prasarana secara bertahap dan membangun perekonomian profesional.

Kurikulum Pendidikan dan Pengajaran Pesantren yaitu dengan mengintegrasikan Kurikulum KMI (Kulliyatul Mu'allimin Al-Islamiyah) Gontor, Kemendiknas, dan Kemenag. Program unggulan berupa Tahfidz AlQur'an, Bahasa Arab dan Bahasa Inggris, Leadershif, Kewirausahaan, dan Kepramukaan. Adapun bahasa pengantar komunikasi yang digunakan dalam percakapan sehari-hari berupa bahasa Arab dan bahasa Inggris. Jenjang pendidikan yang ada dibawah naungan Pondok pesantren Darul Huda Banjar yaitu; 1) MI Plus Daarul Huda, mulai berdiri pada tahun 2017. 2) SMPIT AlFawwaz Daarul Huda (Terakredetasi A). Berdiri tahun 2007. dengan status terdaftar dan diberikan Nomor Statistik Madrasah (NSM): 131232790002. 3) Madrasah Aliyah Daarul Huda (Terakredetasi A). Berdiri tahun 2000 dan diresmikan pada 8 Pebruari tahun 2001. dengan status terdaftar dan diberikan Nomor Statistik Madrasah (NSM): 312320912692. Secara garis besar manajemen kurikulum terpadu Pondok pesantren modern Darul Huda Banjar meliputi: perencanaan, pengorganisasian, pelaksanaan, pengawasan, dan evaluasi kurikulum terpadu. Berikut penjelasan unsur-unsur tersebut

Perencanaan Kurikulum Terpadu

Perancanaan kurikulum terpadu terdiri dari, intra-kurikuler, kokurikuler dan ekstrakurikuler. Intra kurikuler berisi tentang ilmu-ilmu keislaman, ilmu-ilmu bahasa arab, dan ilmu-ilmu umum ('ulum Islamiyah, ulum 'arabiyah, 'ulum 'ammah). Ko-kurikuler berisi tentang ibadah amaliyah, extensive learning, praktik dan bimbingan dilaksanakan di luar jam sekolah dibawah bimbingan guru-guru. Kegiatan ektrakurikuler dilaksanakan di luar sekolah oleh pengurus organisasi santri, di bawah bimbingan guru dan santri senior. Aspek-aspek yang perlu direncanakan dalam perencanaan kurikulum terpadu meliputi: (1) tujuan, (2) program, (3) jadwal kegiatan.

Tujuan; a) terwujudnya generasi yang unggul menuju terbentuknya khaira ummah; b) terbentuknya generasi mukmin muslim yang berbudi tinggi, berbadan sehat, berpengetahuan luas, dan berpikiran bebas, serta berkhidmat 
kepada masyarakat; c) lahirnya ulama yang intelek yang memiliki keseimbangan dzikir dan pikir; d) terwujudnya warga negara yang berkepribadian Indonesia yang beriman dan bertakwa kepada Allah swt.

Program Pendidikan dalam sistem mu'allimin diintegrasikan dengan sistem Pesantren, santri hidup di dalam asrama yang berdisiplin selama 24 jam penuh, dengan bimbingan para guru dan Kyai. Maka kurikulum Mu'allimin tidak terbatas pada pelajaran di kelas saja, melainkan keseluruhan kegiatan di dalam dan di luar kelas merupakan proses pendidikan yang tak terpisahkan. Materi pendidikan yang menjadi program dikembangkan meliputi; keimanan, keislaman, akhlaq karimah, keilmuan, kewarganegaraan/kebangsaan, kesenian dan keindahan (estetika), kewiraswastaan dan keterampilan teknis, dakwah dan kemasyarakatan (khidmah al-ijtimaiyyah), kepemimpinan dan manajemen, keguruan, kepesantrenan, pendidikan kewanitaan (at-tarbiyah an-nisawiyah), pendidikan jasmani dan kesehatan, kepramukaan, tahfidzul qur'an. Jadwal kegiatan yang dilaksanakan meliputi kegiatan harian, mingguan, semesteran dan tahunan.

\section{Pengorganisasian Kurikulum Terpadu}

Struktur Pengurus Pesantren terdiri dari pembina yayasan, ketua yayasan, pimpinan pondok, sekretaris, bendahara, bidang pembinaan alumni, bidang pendidikan (Madin, MI Plus, SMPIT Al Fawwaz, MA Daarul Huda), bidang pengasuhan (pengasuhan santri; OP3M, Mabikor pramuka), bidang usaha, bidang sosial kemasyarakatan. Selanjutnya akan dijelaskan struktur kurikulum dan kegiatan intra-kurikuler, ko-kurikuler ektrakurikuler.

Hasil pengamatan penulis wawancara dengan pimpinan pesantren dan juga staf KMI, kurikulum yang berlaku di Pondok Pesantren Modern Daarul Huda Banjar adalah perpaduan antara kurikulum pendidikan pesantren dengan kurikulum pemerintah (Kementerian Agama, Kementrian Pendidikan dan Kebudayaan), sehingga lulusannya dapat melanjutkan ke jenjang pendidikan yang lebih tinggi, baik di dalam maupun di luar negeri. Kulliyatul Mu'allimin Al-Islamiyah (KMI), dapat ketahui bahwa KMI Pondok Pesantren Daarul Huda Banjar adalah jenjang pendidikan selama 6 (enam) tahun yaitu, I, II dan III yang setara dengan kelas I, II, III SMP dan kelas IV, V dan VI yang setara dengan kelas I, II dan III MA dengan menggunakan kurikulum yang berkolaborasi, sesuai dengan nama Kulliyatul Mu'allimin Al-Islamiyah (KMI), mendidik santrinya untuk mampu mendidik, memimpin dan mampu berdakwah dengan harapan ketika kembali ke daerah masing-masing dengan konsep Islam, agar agama Islam tetap tegak serta KMI telah mampu mencetak alumni-alumni yang berkualitas dan diakui keunggulannya, yang tersebar secara luas dalam berbagai bidang atau profesi. 
Struktur kurikulum PPM Daarul Huda Banjar yang bersistem Kulliyatul Mu'allimin Al-Islamiyah (KMI) terdiri dari Intra-kurikuler, ko-kurikuler dan ekstrakurikuler. Kegiatan intra-kurikuler merupakan kegiatan utama yang dilakukan oleh setiap sekolah atau pesantren yang sudah teratur, jelas dan terjadual. Kegiatan ini terdiri dari beberapa mata pelajaran yang harus ditempuh oleh setiap peserta didik (santri) sesuai dengan jenjang masingmasing. Adapun struktur intra-kurikuler terbagi menjadi beberapa bagian di antaranya sebagai berikut:

Pertama, struktur 'ulum islamiyah berisi mata pelajaran Alquran, tajwid, tafsir, tarjamah, hadits, musthalah hadits, jami al shagir, fiqih, usul fiqih, faraid, tauhid, al-din al-islamy (tsaqofah islamiyah), muqaranat al-adyan, tarikh islam. kedua, struktur ulum 'arabiyah berisi mata pelajaran imla', tamrin lughah, insya', muthala'ah, nahwu, sharaf, balaghah, tarikh adab al-lughah, mahfuzhat (nushush 'arobiyah), al-mu'jam, khath. ketiga, struktur 'ulum 'ammah berisi mata pelajaran bahasa indonesia, bahasa inggris, matematika, fisika, kimia, biologi, geografi, sejarah, kewarganegaraan/pkn, sosiologi, psikologi, keguruan/kependidikan (tarbiyah amaliyah), logika. keempat, materi un/uambn. Struktur kegiatan intra-kurikuler merupakan pola susunan mata pelajaran yang harus ditempuh oleh setiap peserta didik (santri) dalam kegiatan belajar mengajar sesuai dengan jenjang masing-masing. Struktur intra-kurikuler terdiri atas kelompok mata pelajaran keagamaan Islam, kelompok mata pelajaran pendidikan umum, dan muatan lokal.

Menurut Ustadzah Desi Purnamasari, materi di dalam kelas harus menunjang kegiatan di luar kelas. Kegiatan ko-kurikuler merupakan kegiatan yang sangat erat sekali dan menunjang serta membantu kegitan intra-kurikuler yang dilaksanakan di luar jam sekolah di bawah bimbingan guru-guru dan santri-santri senior, yang bertujuan agar peserta didik (santri) lebih memahami materi yang sudah diajar dalam kelas. Adapun struktur kegiatan ko-kurikuler di antaranya sebagai berikut: Pertama, ibadah amaliyah (praktik ibadah) berisi mengenai shalat, puasa, membaca Alquran, dzikir, wirid, dan do'a, tahfidz Alquran, puasa daud. kedua, extensive learning berisi beberapa kegiatan diantaranya; 1) pembinaan dan pengembangan 3 bahasa (arab, inggris, indonesia); 2) belajar muwajjah (tutorial) di malam hari (ba'da magrib); 3) pengkajian kitab-kitab klasik; 4) latihan dan lomba pidato dalam 3 bahasa; 5) cerdas cermat; 6) diskusi, seminar, simposium dan bedah buku (fathul kutub wa bahtsul masail). ketiga, praktik dan bimbingan berisi beberapa kegiatan di antaranya; a) praktik adab dan sopan santun/etika; b) praktik mengajar/keguruan; c) praktik laboratorium ilmu pengetahuan alam; d) praktik laboratorium bahasa; e) praktik dakwah kemasyarakatan (khidmah al ijtimaiyyah); f) praktik manasik haji; g) praktik menyelenggarakan jenazah; h) 
bimbingan dan penyuluhan; i) economic study tour; j) penulisan karya ilmiah (paper) berbahasa Arab dan Inggris; k) bimbingan halaqah tarbawiyah

Adapun mengenai kegiatan ekstra-kurikuler, menurut ustadzah Desi Purnamasari, merupakan kegiatan yang dilaksanakan di luar jam pelajaran atau kegiatan tambahan yang harus ada di pesantren, karena kegiatan ekstrakurikuler juga sangat berpengaruh besar dangan kelulusan dan prestasi peserta didik (santri). Selain dari kegiatan intra-kurikuler, kegiatan ekstrakurikuler juga merupakan kegiatan tambahan di luar struktur program pelajaran yang berfungsi agar memperbanyak dan memperluas wawasan pengetahuan dan kemampuan serta mengembang minat, bakat dan keterampilan para santri. Ekstrakurikuler dilaksanakan di luar sekolah oleh pengurus organisasi santri, di bawah bimbingan guru dan santri senior. Kegiatan ekstrakurikuler ini antara lain meliputi; a) latihan dan praktik berorganisasi (kepemimpinan dan manajemen); b) kursus-kursus dan latihanlatihan (Pramuka, ketrampilan, kesenian, kesehatan, olahraga, perkoperasian, kewiraswastaan, sadar lingkungan, bahasa, jurnalistik, retorika, dan lain-lain); c) dinamika Kelompok Santri (baik kelompok-kelompok wajib, ataupun kelompok-kelompok minat); d) pembekalan calon alumni KMI; e) penugasan alumni di pondok alumni.

Menurut pimpinan pesantren, yang menjadi standar kelulusan santri adalah berakhlak al-karimah (akhlak mulia/terpuji), tidak memiliki tunggakan administrasi keuangan, telah menyelesaikan/lulus ujian pondok dan negara, menyelesaikan hafalan sesuai muqarrar (ketentuan). Dalam sidang kelulusan akblak al-karimah menjadi bahan pertimbangan yang paling menentukan terhadap kelulusan santri, sebagai contoh misalnya seorang santri itu pintar dalam segi akademik namun akhlaknya jelek maka penilaian terhadap hasil akademik bisa berkurang bahkan tidak lulus.

Profil alumni dan kiprah alumni adalah sebagai berikut: a) Mukmin, Muslim, Muhsin. b) Komitment pada perjuangan Islam. c) Perekat ummat. d) Berjiwa guru. e) Warga negara yang baik. Alumni Pondok Pesantren Modern Daarul Huda telah banyak diterima di berbagai Perguruan Tinggi Negeri/Swasta, Dalam dan Luar Negeri; UI, UGM, UIN, UNPAD, UPI, UNSUD, UNIDA, UMY, UNJ, IAIN, LIPIA, TAZKIA, Al-AZHAR CAIRO, SULAIMANIYAH TURKI, dan telah banyak alumni yang berkiprah pada berbagai starata sosial kemasyarakatan; TNI/POLRI, Guru, PNS, Da’i, Pimpinan Pesantren, Wirausahawan, Wartawan, politisi, dan Akademisi.

\section{Pelaksanaan Kurikulum Terpadu}

Hasil penelitian serta wawancara dengan pimpinan pesantren dan juga staff KMI bahwa sistem pendidikan dan juga manajemen kurikulum terpadu yang dilaksanakan di PPM Daarul Huda Banjar adalah sistem mu'allimin atau 
Kulliyatul Mu'allimin Al-Islamiyah (KMI) yang merupakan hasil "ijtihad" para pendiri Pondok Modern Gontor: K.H. Ahmad Sahal; K.H. Zainuddin Fannani; dan K.H. Imam Zarkasyi; yang dilakukan sejak tahun 1926 dalam rangka melakukan "modernisasi" terhadap sistem pendidikan pesantren sebagai "indigenous culture" (budaya asli) bangsa Indonesia sehingga masyarakat kemudian menyebut Pondok Gontor dengan "Pondok Modern".

Semenjak didirikan Pesantren Modern Daarul Huda Banjar Berpola dan merujuk pada sistem KMI Gontor, KMI memang tidak sama dengan sekolah atau madrasah formal, seperti MTs dan MA atau SMP dan SMA atau Madrasah-madrasah Diniyah dan Salafiyah, tetapi secara substansial, KMI/TMI telah memenuhi Standar Nasional Pendidikan seperti yang ditetapkan dalam Peraturan Pemerintah No.19 Tahun 2005, bahkan dalam beberapa aspek melebihi standar tersebut.

Selanjutnya menurut pimpinan pesantren, manajemen kurikulum terpadu adalah perpaduan antara beberapa jenis kurikulum di antaranya kurikulum Kemendikbud (SMPIT Al Fawwaz Daarul Huda), kurikulum Kemenag (Madrasah Aliyah Daarul Huda) dan kurikulum Pesantren yang secara umum perpaduan dalam materi pembelajaran dikelolah dalam satu manajemen kurikulum yaitu, KMI (Kulliyatul Mu'allimin Al Islamiyah) Gontor. Dalam waktu pelaksanaannya disatukan supaya tidak ada pendikotomian antara pesantren dan sekolah, misalnya dalam pembelajaran agama seperti Al-Qur'an Hadis, Fiqih, akidah akhlak, SKI dan bahasa arab menggunakan materi yang dari pesantren, namun ketika akan Ujian Akhir (UAMBN) materi disesuaikan kembali dengan kisi-kisi atau yang akan diujiankan. Secara garis besar materi dalam pembelajaran agama dan bahasa arab di sekolah hampir sama dengan pesantren.

KMI telah mampu mencetak alumni-alumni yang berkualitas dan diakui keunggulannya, yang tersebar secara luas dalam berbagai bidang atau profesi. Salah satu bukti keunggulan tersebut, adalah bahwa system KMI/TMI telah mendapatkan "pengakuan" (mu'adalah) dari berbagai institusi atau universitas di luar negeri, seperti Al-Azhar University, Cairo; Islamic University, Madinah Munawarah; University of The Punjab, Lahore, Pakistan; Al-Zaitun University, Tunisia; International Islamic University Islamabad, Pakistan; International Islamic University, Malaysia; University Kebangsaan Malaysia.

Bahkan sejak tahun 1998, Pemerintah Republik Indonesia secara resmi telah mengeluarkan "Pengakuan Penyetaraan" Ijazah KMI/TMI dengan Ijazah Madrasah Aliyah (MA) dan Sekolah Menengah Atas (SMA), yaitu dengan SK. Dirjen Binbaga Islam Departemen Agama No.E.IV/PP.03.2/KEP/64/98 tanggal 28 Juli 1998; dan SK Menteri Pendidikan Nasional No.105/O/2000 tanggal 29 Juni 2000. Menurut laporan terakhir, "Tim Penyetaraan 
KMI/TMI" yang dibentuk oleh Departemen Pendidikan Nasional telah mengeluarkan SK Pengakuan Penyetaraan serupa terhadap 17 KMI/TMI di seluruh Indonesia, dan masih banyak lagi KMI/TMI lainnya yang akan segera diakreditasi pada masa yang akan datang.

Hasil wawancara dengan pimpinan pesantren, mengapa merujuk pada sistem KMI karena Salah satu sistem pendidikan alternatif yang mendapat pengakuan resmi dari Pemerintah Negara Kesatuan Republik Indonesia melalui rekomendasi dari Badan Standar Nasional Pendidikan, sebagaimana diatur dalam Pasal 93 Peraturan Pemerintah No.19 Tahun 2005 tentang Standar Nasional Pendidikan. Upaya dan usaha Daarul Huda untuk berdiri sebagai Pesantren Modern yang diakui pemerintah.

Hasil wawancara dengan pimpinan pesantren dan juga dewan asatidz bahwa secara umum metode yang diterapkan di PPM Daarul Huda, mempertahankan cara-cara lama yang baik, dan mengakomodasi cara-cara baru yang lebih baik, mengacu pada efektifitas, efisiensi dan akselerasi, berorientasi pada pencapaian tujuan transformasi ilmu dengan pengembangan kepribadian, ditekankan pada upaya-upaya keteladanan, pembiasaan, pembentukan miliu, pengarahan, penugasan, dan pengawasan dengan total quality control.

Adapun metode-metode yang digunakan guru/asatidz dalam pembelajaran adalah sebagai berikut : metode ceramah, metode tanya jawab, metode resitasi, metode driil dan dikte, metode diskusi, metode demonstrasi, metode hafalan/tahfidz

Menurut Pimpinan dan bagian pengasuhan santri, dalam mengaplikasikan pengajaran ditekankan pada upaya keteladanan, pengarahan, penugasan dan pembiasaan. Pertama, keteladanan, dicontohkan oleh Pengasuh, Pimpinan, guru/ustadz, dan santri. Metode ini sangat efektif dalam mendidik karakter, karena sebaik-baik pendidikan adalah dengan perbuatan, bukan sekadar dipidatokan. Kedua, pengarahan, Setiap pekerjaan selalu diawali dengan pengarahan. Hal itulah yang diterapkan dalam proses pendidikan, sehingga memungkinkan santri untuk memahami nilai-nilai filosofis dari setiap apa yang dikerjakan, dan bukan hanya sekadar mengerjakan tugas dan kewajibannya.

Ketiga, penugasan, Diantara metode yang benar dalam mendidik adalah dengan penugasan. santri dapat menghayati nilai-nilai pendidikan setelah mengerjakan tugas yang diberikan, santri diberi tanggung jawab untuk mengerjakan tugas, hal tersebut melatih siswa mampu memecahkan problem yang dihadapinya. Keempat, pembiasaan, metode pembiasaan yang diterapkan cukup efektif di dalam melatih santri untuk melakukan hal-hal yang positif, karena siswa dibiasakan berdisiplin bahkan dengan sedikit paksaan. Menurut bagian pengasuhan santri dan juga pimpinan, bahasa Arab dan bahasa Inggris 
ditetapkan sebagai bahasa pergaulan dan bahasa pengantar pendidikan, kecuali mata pelajaran tertentu yang harus disampaikan dengan Bahasa Indonesia. Bahasa Arab dimaksudkan agar santri memiliki dasar kuat untuk belajar agama mengingat dasar-dasar hukum Islam ditulis dalam bahasa Arab. Bahasa Inggris merupakan alat untuk mempelajari ilmu pengetahuan/umum. Santri diajarkan untuk bersosialisasi dengan membentuk masyarakat sendiri di dalam pondok, melalui organisasi-organisasi. Mulai dari ketua asrama, ketua kelas, ketua kelompok, organisasi intra/ekstra, hingga ketua regu pramuka. Santri juga diwajibkan membiasakan adab dan sopan/santun agar terciptanya lulusan yang berakhlak al-karimah.

Kelima, pencipta Lingkungan, Lingkungan yang kondusif mutlak ada dalam sistem pendidikan asrama, karena kondisi tersebut mendukung terciptanya belajar yang sehat, segala apa yang didengar, dilihat, dan dirasakan oleh siswa adalah merupakan unsur-unsur yang mendidik. Dalam beberapa kesempatan ustadz dapat memberi kepercayaan pembelajaran kepada santri yang dipilih dari para santri senior sebagai upaya latihan bagi para santri senior, namun tetap dibawah pengawasan ustadz yang bersangkutan, selain praktik mengajar di pesantren santri juga harus mengikuti program praktik mengajar/keguruan yang dilaksanakan di luar pesantren, misalnya di SD atau madrasah diniyah bahkan di majlis ta'lim sebagai bekal nantinya untuk di masyarakat. Menurut pimpinan pesantren "Praktik mengajar biasanya dilaksanakan ketika santri kelas $\mathrm{V}$ atau setara dengan siswa kelas $2 \mathrm{MA}$, kelas IV/1 MA sebagai wakilnya”.

Pengawasan Kurikulum Terpadu

Pengawasan merupakan bagian dari fungsi manajemen. Perencanaan, pengorganisasian dan pelaksanaan tidak akan berjalan lancar secara efektif tanpa adanya pengawasan. pengawasan adalah suatu proses di mana pimpinan ingin mengetahui apakah hasil pelaksanaan pekerjaan yang dilakukan oleh bawahannya sesuai dengan rencana, perintah, tujuan atau kebijaksanaan yang telah ditentukan.

Pengawasan kurikulum terpadu di pondok pesantren modern Daarul Huda Banjar, meliputi waktu dan bentuk pengawasan. Pertama waktu pengawasan dilaksanakan secara harian, mingguan, bulanan, semesteran, tahunan. Kedua bentuk pengawasan meliputi: a) Taftisy I'dad (supervisi satuan pelajaran/persiapan mengajar) berupa kontrol koreksian guru. b) Naqd alTadris (supervisi kegiatan pembelajaran). c) Ta'hil al-Mudarrisin (pengayaan materi pelajaran untuk para guru). d) Pengarahan Terpadu Mingguan (Seninan), berupa pengarahan dari pimpinan terhadap guru mengenai kehadiran dan juga materi serta anjuran dalam pembelajaran. e) Rapat-rapat Koordinasi dan Orientasi. 


\section{Evaluasi Kurikulum Terpadu}

Evaluasi kurikulum merupakan sistem penilaian yang sistematis tetang manfaat, kesesuaian efektifitas dari kurikulum yang diterapkan. Evaluasi kurikulum ini dapat mencakup keseluruhan kurikulum atau komponenkomponen yang ada dalam kurikulum seperti tujuan, materi, metode pembelajaran Kulliyatul Mu'allimin Al-Islamiyah (KMI) Pondok Pesantren Modern Daarul Huda Banjar, evaluasi dilakukan dengan prinsip objektif, adil, transparan, terpadu, dan menyeluruh. Semua pengalaman yang dialami oleh santri tidak luput dari penilaian, baik yang bersifat akademis maupun non akademis. Penilaian meliputi aspek kognitif, afektif, dan psikomotor.

Secara garis bersar evaluasi dilaksanakan 2 kali dalam setahun melalui pertengahan tahun dan akhir tahun. Di samping itu ada jenis evaluasi yang diterapkan oleh pesantren berupa ujian masuk, ujian lanjutan, muraja'ah 'ammah (ujian tengah semester), ujian semester dan Ujian Akhir/Niha'ie (UN/UAMBN). Menurut Pimpinan Pesantren, penilaian yang diterapkan Kulliyatul Mu'allimin Al-Islamiyah (KMI) Pondok Pesantren Modern Daarul Huda Banjar, dibagi menjadi 3 (tiga) bentuk evaluasi, yaitu ujian lisan (syafahi), ujian tulis (tahriri) dan ujian praktik (tathbiqi).

\section{Kesimpulan}

Berdasarkan hasil penelitian tentang manajemen kurikulum terpadu di pondok pesantren Daarul Huda Banjar, dapat disimpulkan sebagai berikut: (1) Perancanaan kurikulum terpadu terdiri dari, intra-kurikuler, ko-kurikuler dan ekstrakurikuler, perencanaan kurikulum terpadu meliputi: (1) tujuan, (2) program, (3) jadwal kegiatan. Program pendidikan meliputi; Keimanan, Keislaman, Akhlaq Karimah, Keilmuan, Kewarganegaraan/Kebangsaan, Kesenian dan Keindahan (Estetika), Kewiraswastaan dan Ketrampilan Teknis, Dakwah dan Kemasyarakatan (Khidmah al-Ijtimaiyyah), Kepemimpinan dan Manajemen, Keguruan, Kepesantrenan, Pendidikan Kewanitaan (at-Tarbiyah an-Nisawiyah), Pendidikan Jasmani dan Kesehatan, Kepramukaan, Tahfidzul Qur'an. Santri hidup di dalam asrama yang berdisiplin selama 24 jam penuh dengan bimbingan para guru dan Kyai, jadwal kegiatan terdiri dari Harian, Mingguan, Semesteran dan Tahunan. (2) Pengorganisasian kurikulum yang berlaku di Pondok Pesantren Modern Daarul Huda Banjar adalah perpaduan antara kurikulum pendidikan pesantren dengan kurikulum pemerintah (Kementerian Agama, Kementrian Pendidikan dan Kebudayaan), sehingga lulusannya dapat melanjutkan ke jenjang pendidikan yang lebih tinggi, baik di dalam maupun di luar negeri. KMI Pondok Pesantren Daarul Huda Banjar adalah jenjang pendidikan selama 6 (enam) tahun yaitu, I, II dan III yang 
setara dengan kelas I, II, III SMP dan kelas IV, V dan VI yang setara dengan kelas I, II dan III MA dengan menggunakan kurikulum yang berkolaborasi, sesuai dengan nama Kulliyatul Mu'allimin Al-Islamiyah (KMI), mendidik santrinya untuk mampu mendidik, memimpin dan mampu berdakwah dengan harapan ketika kembali ke daerah masing-masing dengan konsep Islam, agar agama Islam tetap tegak serta KMI telah mampu mencetak alumni-alumni yang berkualitas dan diakui keunggulannya, yang tersebar secara luas dalam berbagai bidang atau profesi.

Pelaksanaan kurikulum terpadu adalah perpaduan antara beberapa jenis kurikulum di antaranya kurikulum Kemendikbud (SMPIT Al Fawwaz Daarul Huda), kurikulum Kemenag (Madrasah Aliyah Daarul Huda) dan kurikulum Pesantren yang secara umum perpaduan dalam materi pembelajaran dikelolah dalam satu manajemen kurikulum yaitu, KMI (Kulliyatul Mu'allimin Al Islamiyah) Gontor. Dalam waktu pelaksanaannya disatukan supaya tidak ada dikhotomi antara pesantren dan sekolah, misalnya dalam pembelajaran agama seperti Al-Qur'an Hadis, Fiqih, akidah akhlak, SKI dan bahasa arab menggunakan materi yang dari pesantren, namun ketika akan Ujian Akhir (UAMBN) materi disesuaikn kembali dengan kisi-kisi atau yang akan diujiankan. Secara garis besar materi dalam pembelajaran agama dan bahasa arab di sekolah hampir sama dengan pesantren. Metode yang diterapkan di PPM Daarul Huda, mempertahankan cara-cara lama yang baik, dan mengakomodasi cara-cara baru yang lebih baik, mengacu pada efektifitas, efisiensi dan akselerasi, berorientasi pada pencapaian tujuan transformasi ilmu dengan pengembangan kepribadian, ditekankan pada upaya-upaya keteladanan, pembiasaan, pembentukan miliu, pengarahan, penugasan, dan pengawasan dengan total quality control. Pengawasan kurikulum terpadu di pondok pesantren modern Daarul Huda Banjar, meliputi waktu dan bentuk pengawasan. Pertama waktu pengawasan dilaksanakan secara harian, mingguan, bulananan, semesteran, tahunan. Kedua bentuk pengawasan meliputi: a) Taftisy I'dad (supervisi satuan pelajaran/persiapan mengajar) berupa kontrol koreksian guru. b) Naqd al-Tadris (supervisi kegiatan pembelajaran). c) Ta hil al-Mudarrisin (pengayaan materi pelajaran untuk para guru). d) Pengarahan terpadu mingguan (Seninan), berupa pengarahan dari pimpinan terhadap guru mengenai kehadiran dan juga materi serta anjuran dalam pembelajaran. e) Rapat-rapat koordinasi dan orientasi. Evaluasi kurikulum terpadu di pondok pesantren modern Daarul Huda Banjar dilaksanakan 2 kali dalam setahun melalui pertengahan tahun dan akhir tahun. Di samping itu ada jenis evaluasi yang diterapkan oleh pesantren berupa ujian masuk, ujian lanjutan, muraja'ah 'ammah (ujian tengah semester), ujian semester dan Ujian Akhir/Niha'ie (UN/UAMBN). Penilaian yang diterapkan 
Kulliyatul Mu'allimin Al-Islamiyah (KMI) Pondok Pesantren Modern Daarul Huda Banjar, dibagi menjadi 3 (tiga) bentuk evaluasi, yaitu ujian lisan (syafahi), ujian tulis (tahriri) dan ujian praktik (tathbiqi).

\section{DAFTAR PUSTAKA}

Al Hamdani, D. (2013). Manajemen Perencanaan Pendidikan. Bandung: Media Cendekia Publisher.

Al Hamdani, D. (2014). Administrasi Pendidikan, Administrasi Pendidikan dari Perspektif Pendidik. Bandung: Media Cendekia Publisher.

Bahasa, T. P. K. P. (2008). Kamus Bahasa Indonesia. Jakarta: Pusat Bahasa Departemen Pendidikan Nasional.

Beane, J. A. (1997). Curriculum Integration: Designing the Core of Democratic Education. New York and London: Teachers College Press, Columbia University.

Diwan, P. (1998). Management Principles and Practices. New Delhi: Anurag Jain.

Engkoswara \& Komariah, A. (2010). Administrasi Pendidikan (Cet. 1). Bandung: CV. Alfabeta.

Fattah, N. (2004). Landasan Manajemen Pendidikan. Bandung: PT. Remaja Rosdakarya.

Griffin, R. W. (2008). Fundamentals Of Management (5th Editio). Boston USA: Houghton Miffin Company.

Hamalik, O. (2011). Dasar-Dasar Pengembangan Kurikulum. Bandung: PT. Remaja Rosdakarya.

Handayaningrat, S. (1995). Pengantar Studi Ilmu Administrasi dan Manajemen. Jakarta: Toko Gunung Agung.

Harjanto. (2003). Perencanaan Pengajaran. Jakarta: Rineka Cipta.

Idi, A. (2011). Sosiologi Pendidikan Individu, Masyarakat dan Pendidikan. Jakarta: Rajawali Pers.

Nasution, S. (2006). Azas-Azas Kurikulum. Jakarta: Bumi Aksara.

Pidarta, M. (2007). Landasan Kependidikan. Jakarta: Rineka Cipta.

Qomariyah, R., \& Soeprajitno. (2016). Studi Kurikulum Pesantren SMP Bilingual Terpadu Di Pesantren Modern Al-Amanah Junwangi Krian Sidoarjo. Jurnal Mahasiswa Teknologi Pendidikan, 10(1), 1-7.

Rusman. (2009). Manajemen Kurikulum. Jakarta: Raja Grapindo Persada.

Sagala, S. (2009). Administrasi Pendidikan Kontemporer. Bandung: CV. Alfabeta.

Samdani. (2014). Implementasi Kurikulum Terpadu di Sekolah Dasar Islami Terpadu Qardhan Hasana Banjarbaru. Jurnal Tarbiyah Islamiyah, 1(2), 
$1-41$.

Tisnawati, E. S. dkk. (2005). Pengantar Manajemen. Jakarta: Kencana Prenada Medi Grup.

Usman, H. (2006). Manajemen, Teori, Praktik dan Riset Pendidikan. Jakarta: Bumi Aksara. 
